\title{
The Comparison of the Skill of Understanding Complex Syntax at Children Attending to a Preschool Education Institution (TRNC-TR Sample)
}

\author{
Elçin Yazıcı \\ Department of Early Childhood Education, Faculty of Education Elementary Education, Duzce University, Turkey
}

Copyright $(2016$ by authors, all rights reserved. Authors agree that this article remains permanently open access under the terms of the Creative Commons Attribution License 4.0 International License

\begin{abstract}
The current study was carried out to compare the skills of understanding complex syntax at children attending to preschool education institutions. In the current study, relational screening model, a model providing to determine the current study, was used. The working group of the study was made up of 224 children at the age of 4-5 attending to a preschool education institution in Turkey and Cyprus in the educational year of 2015-2016. In order to gather general information regarding the children and their families, "General Information Form" was used and "The Instrument of Evaluating the Criteria Dependent Complex Syntax Understanding Skills (ECDCSUS)", which was developed by Akoğlu and Acarlar (2012), was used to compare the skills of understanding complex syntax at children as a data collection instrument. So as to explain what level children's skills of understanding complex syntax, standard deviation and mean values of children's skills of understanding complex syntax were given in the study. In order to determine whether there was a difference between the skills of understanding complex syntax of the children attending to a preschool education institution in Turkey and Cyprus and the skills of understanding complex syntax of children at the age of 4 and 5, Mann Whitney U-Test was used in terms of the items of ECDCSUS. At the end of the research, it was found that the scores of the skills of understanding complex syntax at children attending to a preschool education had a statistically significant difference in terms of country and age variables.
\end{abstract}

Keywords Understanding Complex Syntax, Preschool Education

\section{Introduction}

The skill of understanding syntax is defined as understanding new sentences bearing messages by getting information regarding grammar or syntax [20]. At the same time, the skill of understanding syntax is a complex skill being able to use the words within the former context that requires analysing at the level of words of the written or verbal knowledge. For that reason, more than one mechanism is busy with the level of the process during understanding. These processes are influenced from a greater language content and close surrounding in terms of current knowledge and amount [23].

From the start of modern psycholinguistic onwards, individuals have focused on syntactic processes in understanding language [13]. Understanding complex structures of a sentence is supported by syntactic and semantic knowledge [12]. For that reason, during the process of understanding the structure of sentences, the interaction between syntactic differentiation and semantic integration is of importance [17]. Psycholinguistics deals with the phenomenon of understanding sentence structures in different ways. Some theorists focus on the fact that there is a system of understanding the structure of a sentence in setting up new representations. Some others point out the importance of grammar, words and contextual information in understanding the structure of sentence. Understanding the sentence that is set up in written or verbal form needs analysing. The syntax of a language is the psycholinguistic field determining the rules of both synthesis and analysis of the meaningful units $[20 ; 4]$. In this sense, understanding the structure of a sentence in a correct way requires the skills of complex psycholinguistic processing. The skills of complex psycholinguistic processing have various definitions with regard to phonetical, syntactical and semantical process, however, the chronological age of the individual is said to have an impact on his understanding and defining a skill [14]. It was stated in some researches that different structures of sentence could be developmentally distinctive at different age periods, also active and reversible sentences are perceived earlier than passive ones, and the importance of syntactic knowledge increased compared to contextual clues 
during understanding the sentence with the age of five, and that chronologies age could be a significant determinant [1]. The task of setting up a sentence is the process of transferring serial elements into stigmatic dimension, in other words, synthesising them. For that reason, the task of setting up a sentence comprises more than making a series of storage of words and sounds. The brain estimates the following word in the sentence depending on syntactic design, grammar and pragmatic clues. Meaning is found in words one by one or as a combination [15].

In early childhood period, the skill of analysing the phonetical, syntactical and semantical structure of a sentence and perceiving the meaning of it is limited to the assessment of observable behaviours. It was pointed out that the features affecting the understanding of a sentence structure are the complex relations resulting from the message itself such as the difficulty level of the sentence, the length and the content of information it has, as well as semantic frequency rather than the listener himself. The place of the pausing, the speed of the speaker and also the features determining the skill of a child have an impact on the quality of information regarding syntactical structure. It is stated that psychological, linguistic and acoustic features have an effect on understanding the structure of a sentence and that it is necessary to support the strategies of understanding from early ages onwards in language acquisition [14].

Language acquisition is a must in understanding and a process continually going on in early childhood period [10]. Language development is important in language acquisition. The fields of language development (phonology, lexicology and syntax) is set up over understanding the spoken language earlier than the active production of phonemes, words and grammar structures. Early linguistic skills of children are of great importance on their development of verbal language and understanding the spoken language $[11 ; 18]$. Children acquire a great many words and grammar structures in both language production and understanding it at about six years of age. Some complex structures (such as passive, transitive and relative sentences) could not be used correctly before the age of eight or nine. For that reason, it was pointed out that neurobiological support given to the ongoing language development in recent years has been so widespread. The areas in understanding and producing language were determined in the $19^{\text {th }}$ century. There are a great many functional screening studies with regard to the fact that more structures are included, not only Broca field in left inferior lob and left angle girus Wernicke field in understanding language production and understanding [11].

It has been found in some studies carried out into brain recently that some information of the individual's brain, particularly prefrontal cortex do not mature until early adulthood. Complex cognitive functions also carry on developing towards adolescence or early adulthood [22]. Language development is a basis for social and academic success, at the same time. Language acquisition at children could differ depending on social and cognitive variables [10]. In some studies, it was found that the skill of syntactical understanding is closely related to academic success. The action of the body of rules comprising syntactical structure enabling meaningful units to turn into bigger meaningful units proves the existence of mental grammar thought to exist in the brain of child in the process of acquisition [1]. In order to be able to use and understand language in an effective way, it is necessary to know the rules comprising lexical structure [21]. Syntactical structure represents the system of rules giving the rank of words in the sentence, sentence arrangement and the relation between words [15].

In every language system, the body of rules arranging the combination of words in that language in order to set up meaningful sentences and clauses is called "syntactical knowledge" [1]. Vocabulary is important in syntactical knowledge. It is expressed that vocabulary is one of the variables affecting understanding the sentence. Even though there is a relation between vocabulary and reading skills, syntax is also of importance for particularly reading competence in understanding. Syntax is related to decoding in both verbal language and understanding what is read. The relation between the two skills is explained as the fact that syntax leads to understanding verbal language and that a developed language leads to understanding what is read. It was found in some studies that understanding sentence at the age of 7 is related to understanding sentence at the age of 11 [18]. As a matter of fact, some types of words could be used in in different forms such as nouns and verbs. When a new word is taught, children put it in a syntactical category temporarily. They either approve putting it in syntactical category or make suitable changes by indicating how the word is used by others. As an example; a 20-month-old baby is given human and nonhuman shapes. With the figures shown the baby in an order saying "show me x" or "show $\mathrm{x}$ to me", syntactic structures that guides in learning words are determined. Making necessary explanations when children are read books where different words are used help them enrich their vocabulary, learn the meanings of words and acquire syntactical category. In this way, both semantic and syntactic factors play an important role in the emergence of language form [15].

Defining pictures containing syntactical factors, works used in the manipulation and sentence imitation of objects all affect the performance variables of audial, visual, motor and intermodality. All of them show the competence that an individual must have in the analysis of a sentence [14]. With the syntactical rules, the structure or form of a sentence is determined. These rules comprise words, the rank of words, sentence organization, word groups and sentence components. Sentences are arranged according to general functions. Basic components of a sentence include such expressions as noun, verb, adjective etc. comprised of various classes of words. The group of words could be erased or added in a certain expression. As long as there are noun and verb, it is possible to set up a sentence. Hence, it is necessary that every sentence must have a noun and a group of verbs. In this way, syntactical structure is formed with combining the words in a sentence in a way that they can 
have a certain meaning [15]. Syntactical structure overlaps with receptive and expressive language skills. The complex sides of syntactical skills has an important effect upon understanding what is read. In particular, it is stressed that receptive language is of importance to understand the verbal language and use it, and for the skills of reading and writing as well. It is indicated that the methods supporting the development of syntactical skills also supports the skill of understanding at children [18].; since the skill of understanding syntax is expressed as sensibility against the structure of language [20].

For that reason, it is of great importance to examine the skills of understanding syntax which has a great impact on the quality of communication in different groups. In this sense, the current study was carried out to compare the skills of understanding complex syntax at children attending to preschool education institutions.

a. Which level are the skills of understanding complex syntax of the children attending to a preschool institution in Turkey and Cyprus?

b. Is there any difference between the skills of understanding complex syntax attending to a preschool education institution in Turkey and in Cyprus?

c. Do the skills of understanding complex syntax at children differ in terms of age variable?

\section{Materials and Methods}

The model, working population and sampling, data collection instrument, the collection and the analysis of the data were given in this part.

\subsection{The Model of the Study}

In the current study, relational screening model, a model providing to determine the current study, was used. This survey method is a research approach aiming at describing a status in the past or present or an event as it is. Relational screening model is a kind of model aiming at determining the covariance existence and level between two or more variables [9].

\subsection{Working Group}

The working group of the study was made up of 224 children at the age of 4-5 attending to a preschool education institution in Turkey and Cyprus in the educational year of 2015-2016. It was found that $43.3 \%$ of the children chosen for the working of the study randomly were at the age of four and $56.7 \%$ were five.

\subsection{Data Collection Instrument}

In order to gather general information regarding the children and their families, "General Information Form" was used and "The Instrument of Evaluating the Criteria
Dependent Complex Syntax Understanding Skills", which was developed by Akoğlu and Acarlar (2012), to compare the complex syntax understanding skills of children was used as a data collection instrument.

In the formation of the sentences given in The Instrument of Evaluating the Criteria Dependent Complex Syntax Understanding Skills the words of name and action and suffixes widely used by children at the ages of 4-6 at the database of the language sample analysis program of SALT were used. Two different sentences were formed for the each suffix chosen. The sentences comprising infinitives, participles, adverbs, conjunctions, prepositions, negative suffixes and conditional suffixes, as well as reversible sentences were given in the list. For each sentence in the list comprising simple and complex structures, a total four pictures, one showing the sentence uttered and the others prepared with three distracted pictures, were depicted by a professional painter. While preparing distracted pictures, the action in the sentence, the people carrying out this action and the way of carrying out the action were changed. In the rank of the sentences and the distracted pictures, it was paid attention on the fact that the sentences having the same suffixes should not follow each other and the pictures representing the sentence uttered should not take place at the same line. There were a total sum of 34 evaluation sentences differing in terms of syntactical sense and two exercise sentences in the evaluation instrument. During the application, it was expected that the picture representing the sentence uttered by the applicator should be shown and the answers, whether true or false, were marked in the registration form [1]. The Instrument of Evaluating the Criteria Dependent Complex Syntax Understanding Skills was applied in three sets in a way to provide equal distribution. The results regarding One Way Variance Analysis (ANOVA) showed that there was no statistically significant difference between the results obtained through The Instrument of Evaluating the Criteria Dependent Complex Syntax Understanding Skills applied in the working group in different sets $(F 2,45=.038, p>.05)$. [2].

\subsection{Data Collection and Data Analysis}

A consent allowing children to participate the study was taken from the families of the children participating in the working group of the study in order to investigate the skill of understanding complex syntax at children attending to a preschool education institution. The evaluations made with the children given a permission by their families to participate the study were conducted by the researcher individually with each child in the working group and in the institutions where they have their education. During the application of the Instrument of Evaluating the Criteria Dependent Complex Syntax Understanding Skills, the children were asked to show the correct picture suiting the sentence uttered the most among four pictures and it was marked in the registration form with the picture number children showed. Total number of the pictures shown 
correctly was calculated for each children. The evaluations were completed in one session for each child and each session lasted about 35 minutes.

The data of the research was analysed on SPSS 20, the statistical program. In order to make a descriptive analysis of the data obtained through the Instrument of Evaluating the Criteria Dependent Complex Syntax Understanding Skills, arithmetic mean and standard deviation were used and the normality distribution of the data was analysed through Kolmogorov-Smirnov test. In the case of group mass was smaller than 50, Shapiro-Wilks was used, in the case of being bigger, Kolmogorov - Smirnov test was used. In the case an equality both tests were used [6]. At the end of the normality test of Kolmogorov-Smirnov test, it was found that the data did not exhibit normal distribution $(\mathrm{p}<0.05)$.

Table 1. Kolmogorov-Smirnov Test Results Regarding the Normality of the Distribution

\begin{tabular}{|c|c|c|c|}
\hline \multirow{2}{*}{ ECDCSUS } & \multicolumn{3}{|c|}{ Kolmogorov-Smirnov $^{\mathrm{a}}$} \\
\cline { 2 - 4 } & Statistics & $\mathrm{df}$ & Sig. $=\mathrm{p}$ \\
\hline General &, 110 & 224 &, 000 \\
\hline
\end{tabular}

As given in Table 1, it was found that the data did not have a normal distribution for both the general sense of the instrument $[\mathrm{df}(224)=0,110 ; p=0,00]$, and all items. For that reason, non-parametric tests were used in the analysis of the data.

At the end of the normality test of the data analysis: Mann Whitney U-Test was used in terms of the items of the Instrument of Evaluating the Criteria Dependent Complex Syntax Understanding Skills in order to determine whether there was a difference between the skills of understanding complex syntax of the children attending to a preschool education institution in Turkey and Cyprus and the skills of understanding complex syntax of children at the age of 4 and 5. While investigating the difference between categorical variables, 0.05 was used as the significance level and in the case of being $p<0.05$, it was found that there was a significant difference between the groups and in the case of $p>0.05$, it was found that there was no significant difference between the groups [7].

\section{Findings and Discussion}

As a result of the analysis of the data obtained in the research, the findings of the research regarding the analysis of the data that was carried out to determine whether there was a significant difference between the skills of understanding complex syntax of the children attending to a preschool education institution in Turkey and Cyprus and to determine the skills of understanding complex syntax of children at the age of 4 and 5 with the arithmetic mean and standard deviation table regarding the analysis of data in order to make a descriptive analysis of the data obtained in the Instrument of Evaluating the Criteria Dependent Complex Syntax Understanding Skills in compliance with the purpose of the research while forming the part were given below.

The arithmetic mean and standard deviation distribution of the scores regarding the understanding skill of complex syntax of the children attending to an education institution were given in Table 2.

Table 2. The Arithmetic Mean and Standard Deviation Distribution of the Scores Regarding the Understanding Skill of Complex Syntax of The Children

\begin{tabular}{|c|c|c|c|c|c|}
\hline ECDCSUS & count & Min. & Max. & Mean & $\begin{array}{c}\text { Stand. } \\
\text { Deviate. }\end{array}$ \\
\hline $\begin{array}{c}\text { Total Performance of } \\
\text { Understanding } \\
\text { Syntax }\end{array}$ & 224 & 10,00 & 32,00 & 24,22 & 4,35 \\
\hline
\end{tabular}

As given Table 2, the mean scores regarding the total performance of understanding complex syntax of the children were $24.22(\mathrm{SD}=4.35)$.

Akoğlu (2014), found in the work called the Skills of Understanding Syntax at Turkish Children at 4-7 ages that the means regarding total performance of understanding syntax was $25.01(\mathrm{SD}=4.17)$ [1].

It is likely to say that the findings of the research match up with those obtained at the Instrument of Evaluating the Criteria Dependent Complex Syntax Understanding Skills in terms of the means and standard deviations regarding the total performance of understanding complex syntax of the children as given in Table 2. In line with these results, it is likely to think that the skills of understanding complex syntax are very close to each other in terms of the mean scores of the children attending to preschool education institutions in Turkey and Cyprus.

Mann Whitney U-Test results of the skills of understanding complex syntax of the children attending to a preschool education with regard to country variable were given in Table 3.

Table 3. Mann Whitney U-Test Results of the Instrument of Evaluating the Criteria Dependent Complex Syntax Understanding Skills in terms of Country Variable

\begin{tabular}{|c|c|c|c|c|c|}
\hline \multirow{2}{*}{ ECDCSUS } & Country & count & $\begin{array}{c}\text { Rank } \\
\text { Mean. }\end{array}$ & \multicolumn{2}{|c|}{ Mann Whitney } \\
\cline { 5 - 6 } & & $\mathrm{U}$ & $\mathrm{p}$ \\
\hline $\begin{array}{c}\text { Total } \\
\text { Performance of } \\
\begin{array}{c}\text { Understanding } \\
\text { Syntax }\end{array}\end{array}$ & Turkey & 124 & 125,00 & 4650,0 &, 001 \\
& Cyprus & 100 & 97,00 & & \\
\hline
\end{tabular}

As shown in Table 3, it was found that the skills of understanding complex syntax of the children attending to a preschool education institution had a statistically significant difference in terms of country variable between the scores of the understanding skills of general syntax $(U=4650.0 ; \mathrm{p}<.05)$. It is striking that the rank mean of the scores of the understanding skills of complex syntax regarding the items was higher in children attending to a preschool education institution in Turkey.

Upon the reviewing the correct and incorrect answers given to the evaluation instrument of the understanding skills of complex syntax of the children attending to a preschool 
education institution in Turkey and Cyprus in the working group, it was found that the understanding performance of syntax regarding the sentences of "The man isn't wearing his watch cap even though it is snowing/The mother makes the child wear an apron in order not to dirt her dress/If the girl had had a pencil and paper, she would have been able to draw a picture/The child wants to buy an ice-cream/If the child had worn his coat, he would not have been cold/As the child has given flower, his mother kisses him" were higher for the children in Turkey. As for the children attending to a preschool education in Cyprus, it is striking that the number of correct answers given regarding the understandings skills of complex syntax sentences of "The balloon with which the dog was playing burst/The child isn't sleeping even though it is night/The girl took the ball after wearing her shoes/The girl took her coat and bag from the wardrobe/The child took the toothbrush to brush his tooth" were higher than those in Turkey. In addition, it was found that children both in Turkey and in Cyprus gave similar answers to the sentences of "While the mother is cooking, the father is reading a book/The man looks like the bird flying/The dog caught the ball and sat/The child opened the door of the cage so that the bird can go out/The cat and its kitten are drinking milk/The child is kissing his mother/The child is asking for food by crying".

In their studies, Arciuli \& Simpson (2011) found that there is some individual difference in learning visual series of the non-linguistic stimulus in children at the age of 5-12. These differences could be related to language competence and understanding sentence structures. [3].

In their studies, Kidd \& Arciuli (2016) investigated the individual differences in statistical learning included in language acquisition. They applied a test of understanding four syntax structures in children at the age of 6-8. As a result of the study, the individual differences in statistical learning in children are related to the syntax acquisition of the natural language [10].

Upon the review of the related literature, there is an emphasis on the fact that the understanding skill of complex syntax is one of the cognitive functions regarded as a must for behaviour to the purpose and carrying on developing depending on prefrontal cortex growing. Considering the efficiency of the information transfer, it is considered that children at the ages of $5-15$ could perceive complex sentence structures [22].

Again, it is indicated in the literature that language acquisition varies according to social and cognitive variables and that it is also realized in a coordination. Such social environment and current communication and technological means as family, surrounding, school, TV, community, the Internet have an impact to a great extent on the language acquisition of children in healthy way. For that reason, it is necessary that close circles, family at the first rank, and educators should be sensible $[8 ; 10]$.

It is likely to say that the results of the current study and the related literature are in compliance with the findings obtained depending on the country variable of the understanding skill of complex syntax of the children attending to a preschool education institution given in Table 3. In line with these results, it is likely to think that the individual differences in children in Turkey and Cyprus bring about the differences in their understanding skills of syntax depending on the fact that the environmental conditions where children live and the opportunities offered to them.

Mann Whitney U-Test results of the understanding skill of complex syntax of the children attending to a preschool education institution in terms of the age variable was given in Table 4.

Table 4. "The Instrument of Evaluating the Criteria Dependent Complex Syntax Understanding Skills" Mann Whitney U-Test Results in terms of Age Variable

\begin{tabular}{|c|c|c|c|c|c|}
\hline \multirow{2}{*}{ ECDCSUS } & \multirow{2}{*}{ Age } & \multirow{2}{*}{ count } & \multirow{2}{*}{$\begin{array}{l}\text { Mean } \\
\text { Rank }\end{array}$} & \multicolumn{2}{|c|}{ Mann Whitney } \\
\hline & & & & $\mathrm{U}$ & $\mathrm{p}$ \\
\hline \multirow{2}{*}{$\begin{array}{c}\text { Total } \\
\text { Performance of } \\
\text { Understanding } \\
\text { Syntax }\end{array}$} & 4 & 97 & 73,43 & \multirow[b]{2}{*}{2369,5} & \multirow[b]{2}{*}{, 000} \\
\hline & 5 & 127 & 142,34 & & \\
\hline
\end{tabular}

As shown in Table 4, it was found that the skills of understanding complex syntax of the children attending to a preschool education institution had a statistically significant difference in terms of age variable between the scores of the understanding skills of general syntax $(U=2369.5 ; p<.05)$ and that the scores of the understanding skills of complex syntax was higher in children at the age of 5 .

Upon the reviewing the correct and incorrect answers given to the evaluation instrument of the understanding skills of complex syntax of the children attending to a preschool education institution in the working group, it was found that children at the age of 5 answered the sentence "Mouse and cat are playing together" correctly at the rate of $96 \%$ and 4 year children answered the sentence "The dog caught the ball and sat" correctly at the rate of $88.6 \%$, and it is striking that these sentence are among the ones having no difficulty. As for the incorrect sentences children answered (distracted pictures are shown instead of the one representing the sentence uttered), it was found that 5 year old children had a difficulty in the sentence "The child will pick up the apple if he climbs up the ladder" and 4 year old ones had a difficulty in the sentence "The child will wash his hands if he turns the tap on". As for the sentences with the similar sentences by the children, it was found that 4 year old children answered the sentences "If the child had worn his coat, he would not have been cold/The child had washed his hands before eating his meal" $64.9 \% / 67.0 \%$ and 5 year old children answered them $66.1 \%$ and $68.5 \%$, respectively.

In their studies called event and possibility effect of understanding sentence in children, non-verbal content and syntactic form and strategies, Strohner \& Nelson (1974), investigated sentence understanding applications by children at the age group of 2-5. It was found in the study that three year old children had continual mistakes during application of syntactical strategies while those at the age of five had 
reliable information in syntax and they commented the sentences in a correct way [19].

In their study, Booth, MacWhinney \& Harasaki (2000) found that older children developed more in terms of correctness compared to younger ones in the skills of understanding complex language [5].

In their studies called the development of the skill of understanding complex syntax according to age, Wassenberg, Hurks, Hendriksen, Feron, Meijis,Vles \& Jolles (2008) investigated the correctness of understanding complex syntax of children attending to kindergarten, second, fourth, sixth, seventh and eighth grades. At the end of the study, it was found that the correctness of understanding language went on depending on the age [22].

In a study called the skills of understanding syntax in Turkish children at the ages of 4-7 by Akoğlu (2014), it was found that the performance of understanding syntax of children differed in terms of age and as the age interval increased, so did the means [1].

With the review of the related literature, it was indicated that the skill of understanding complex language structure goes on growing up to the start of adolescence period, chronological age is an important factor on the skill of understanding and that there is an interaction between the type of the sentence and chronological age during the process of understanding syntax $[22 ; 1]$.

It is likely to say that the results of the current study and the related literature are in compliance with the findings obtained depending on the age variable of the understanding skill of complex syntax of the children attending to a preschool education institution given in Table 4. Depending on these results, it is also likely to think that the skills of understanding syntax regarding the developmental features of children is realized together with the chronological age and as the age increases, so do the means.

\section{Conclusions and Recommendations}

At the end of the research investigating the skills of understanding complex syntax at children attending to a preschool education, it was found that the mean scores regarding the total performance of understanding complex syntax of the children were $24.22(\mathrm{SD}=4.35)$. In addition, the scores of the skills of understanding complex syntax at children attending to a preschool education had a statistically significant difference in terms of country variables and it was found that it was higher in children attending to a preschool education institution in Turkey. When it comes to investigating the skill of understanding complex syntax of children it terms of age variable, there was a statistically significant difference between the skill scores obtained in "The Instrument of Evaluating the Criteria Dependent Complex Syntax Understanding Skills", and that the scores of the skill of understanding complex syntax was higher at 5 year old children.

In the light of the data obtained in the study, the following recommendations are offered:

- In order to increase the competency levels of children regarding language acquisition, the acquisitions and indicators in language development field taking place in the educational program of preschool education could be prepared in a way to make children attain the skills of understanding syntax in the process of learning.

- Because of the fact that there are so many variables affecting the skills of understanding complex syntax at children, these skills could be worked in terms of different variables and carried out with larger and different groups.

- The current study developed for the children attending to a preschool education institution could be carried out with different age groups in a comparative way.

\section{REFERENCES}

[1] Akoğlu, G. (2014). 4- 7 Yaş Arası Türk Çocuklarında Sözdizimini Anlama Becerileri. Başkent University Journal of Education, 1(2), 31-42.

[2] Akoğlu, G., \& Acarlar, F. (2012). Gelişimsel Dil Bozukluğu Olan Ve Normal Gelişim Gösteren Çocuklarda Sözdizimini Anlama ve Sözel Çalışma Belleği Arasındaki İlişkinin İncelenmesi. $17^{\text {th }}$ National Psychology Congress, Boğaziçi University, İstanbul.

[3] Arciuli, J., \& Simpson, I. C. (2011). Statistical Learning In Typically Developing Children: The Role Of Age And Speed Of Stimulus Presentation. Developmental Science, 14, 464-473.

[4] Börekçi, M. (2015). Söz Dizim Kuramları Bağlamında Türkçe Söz Dizimi. International Periodical for the Languages, Literature and History of Turkish or Turkic, 10(16),355-370.

[5] Booth, J. R., MacWhinney, B., \& Harasaki, Y. (2000). Developmental Differences in Visual and Auditory Processing of Complex Sentences. Child Development, 71, 981-1003.

[6] Büyüköztürk, Ş. (2009). Sosyal Bilimler İçin Veri Analizi El Kitabı. (10.Bask1). Ankara: Pegem Akademi Publishing.

[7] Büyüköztürk, Ş., Kılıç Çakmak, E., Akgün, Ö.E., Karadeniz, Ş., \& Demirel, F. (2012). Bilimsel Araştırma Yöntemleri. Ankara: Pegem Akademi Publishing .

[8] Kabadayı, A. (2012). Okulöncesi Çocuklarının Türkçe Ediniminde Yaptıkları Kurallaştırma Hatalarının İncelenmesi. International Periodical For The Languages, Literature and History of Turkish or Turkic, 7(3), 1561-1573.

[9] Karasar, N.(2007). Bilimsel araştırma yöntemi (17. Baskı). Ankara: Nobel Publishing.

[10] Kidd, E. \& Arciuli, J. (2016). Individual Differences in Statistical Learning Predict Children's Comprehension of Syntax. Child Development, 87(1), 184-193. 
[11] Lidzba, K., Schwilling, E., Grodd, W., Krägeloh-Mann, I. \& Wilke, M. (2011). Language Comprehension vs. Language Production: Age Effects on Fmr1 Activation. Brain \& Language, 119, 6-15.

[12] Malaia, E. \& Newman, S. (2014). Neural Bases of Event Knowledge And Syntax Integration in Comprehension of Complex Sentences. Neurocase: The Neural Basis of Cognition,1-15.

[13] McKoon, G. \& Ratcli, R. (2007). Interactions of Meaning And Syntax: Implications For Models Of Sentence Comprehension. Journal of Memory and Language, 56, 270-290.

[14] Nelson, N.W. (1976). Comprehension of Spoken Language By Normal Children As a Function of Speaking Rate, Sentence Difficulty, and Listener Age And Sex. Child Development, 47, 299-303.

[15] Owens, E.R. (2012). Language Development. An Introduction (8th ed). State University of New York at Geneseo, Pearson, Boston.

[16] Özdamar, K. (2010). Paket Programlar İle İstatistiksel Veri Analizi (Cilt. 1). Eskişehir: Kaan Bookstore.

[17] Palolahti, M., Leino, S., Jokela,M., Kopra, K. \& Paavilainen, P. (2005). Event-related Potentials Suggest Early Interaction Between Syntax and Semantics During On-Line Sentence Comprehension. Neuroscience Letters, 384, 222-227.
[18] Phillips, B. M. (2014). Promotion of Syntactical Development and Oral Comprehension: Development and Initial Evaluation of a Small-Group Intervention. Child Language Teaching and Therapy, 30(1), 63-77.

[19] Strohner, H. \& Nelson, K.E. (1974). The Young Child's Development of Sentence Comprehension: Influence of Event Probability, Nonverbal Context, Syntactic Form, and Strategies. Child Development, 45, 567-576.

[20] Treiman, R., Clifton, C., Meyer, A. S., \& Wurm, L. H. (2003). Language Comprehension And Production. Comprehensive Handbook of Psychology, Volume 4: Experimental Psychology. New York: John Wiley \& Sons, inc.

[21] Yıldırım Erişkin, A. (2013). Normal Gelişim Gösteren, Down Sendromlu Ve Otizmi Olan Çocukların Temel Kavramları Ille Ortalama Sözce Uzunlukları Arasındaki İlişkinin Incelenmesi. Unpublished Doctorate Thesis Ankara University, Institutie of Educational Sciences, Ankara.

[22] Wassenberg, R., Hurks,P.P.M., Hendriksen,J.G.M., Feron, FJ.M., Meijis,C.J.C., Vles, J.S.H., \& Jolles, J. (2008). Age-related İmprovement İn Complex Language Comprehension: Results of A Cross-Sectional Study With 361 Children Aged 5 to 15. Journal of Clinical and Experimental Psychology, 30(4), 435-448.

[23] Wlotko, E. W. \& Federmeier, K. D. (2012). Age-related Changes in The İmpact of Contextual Strength on Multiple Aspects of Sentence Comprehension. Psychophysiology, 49, 770-785. 